\title{
Чумичкин А.C. \\ Особенности классификации потерпевших от преступлений,совершаемых в отношении сотрудников органов внутренних дел
}

Академия управления МВД России

(Россия, Москва)

doi:10.18411/spc-22-11-2017-22

idsp: 000001:spc-22-11-2017-22

Одним из важнейших признаков состава исследуемых преступлений является специальный потерпевший, а именно: сотрудник органа внутренних дел МВД России, а если быть конкретнее, то:

- следователи, а также лица, производящие дознание;

- лица, осуществляющие оперативно-розыскную деятельность;

- сотрудники органов внутренних дел, осуществляющие охрану общественного порядка и обеспечение общественной безопасности, а также исполнение приговоров, определений и постановлений судов (судей) по уголовным делам, постановлений органов расследования и прокуроров.

Вышеуказанные лица могут выступать в качестве потерпевших при совершении в отношении них преступления, предусмотренного ст. 317 УК РФ.

Статья 317 УК РФ ставит под защиту деятельность потерпевших по охране общественного порядка и обеспечению общественной безопасности. Понятие такой деятельности выработано условно-правовой теорией и судебной практикой.

Деятельность по охране общественного порядка - законная деятельность, направленная на предупреждение и пресечение правонарушений (в том числе преступлений), затрагивающих интересы неопределенного круга лиц (обеспечение правопорядка на улицах, площадях, в парках, на транспортных магистралях, вокзалах, аэропортах и иных общественных местах, выявление обстоятельств, способствующих совершению правонарушений и т.п.).

Деятельность по обеспечению общественной безопасности - законная деятельность, направленная на поддержание необходимой степени защищенности жизненно важных интересов неопределенного круга лиц от различных угроз (оказание помощи находящимся в беспомощном или ином состоянии, опасном для их жизни или здоровья, контроль за соблюдением стандартов безопасности дорожного движения, контроль за соблюдением правил обращения с огнестрельным оружием, боеприпасами к нему, взрывчатыми материалами и т.п.).

В рассматриваемом аспекте нельзя не согласиться с мнением С.И. Курилова, который считает, что «преступность как объективное социальное явление можно контролировать, воздействовать на нее различными мерами, которые объединяются одним термином - противодействие»[8]. Данное противодействие на наш взгляд и заключаться именно в деятельности по охране общественного порядка и деятельности по обеспечению общественной безопасности.

Согласно УПК РФ, следователи и лица, производящие дознание, обеспечивают быстрое и полное раскрытие преступлений, изобличение виновных, сбор доказательств, производство дознания и предварительного расследования по уголовным делам, что не относится к деятельности по охране общественного порядка или обеспечению общественной безопасности. Таким образом, указанные лица не могут быть 
потерпевшими по ст. 317 УК РФ, а посягательство на них образует состав ст. 295 УК РФ.

Согласно Федеральному закону от 12.08.1995 № 144-Ф3 (в ред. от 06.07.2016) «Об оперативно-розыскной деятельности», ее задачи в числе других - выявлять, пресекать, раскрывать преступления, а также устанавливать виновных. Поэтому оперативно - розыскная деятельность в этой части служит охране общественного порядка, а лица, ее осуществляющие, могут быть потерпевшими по ст. 317 УК РФ. Эта деятельность входит в компетенцию оперативных подразделений органов внутренних дел.

К числу потерпевших по ст. 317 УК РФ относятся также сотрудники полиции, охраняющие общественный порядок и обеспечивающие общественную безопасность, в соответствии с Федеральным Законом «О полиции» от 07.02.2011 № 3-Ф3 (в ред. от 29.07.2017). Сотрудники других, не полицейских, служб МВД могут быть потерпевшими по ст. 317 УК РФ лишь в том случае, если они привлечены к охране общественного порядка и обеспечению общественной безопасности (например, следователи, дознаватели, работники других служб МВД, которые привлекаются к охране порядка во время массовых мероприятий, стихийных бедствий и т.п.).

Таким образом, те сотрудники органов внутренних дел, деятельность которых связана с пресечением преступности, также охраняют общественный порядок и обеспечивают общественную безопасность, в связи с этим могут быть признаны потерпевшими при совершении данного преступления.

Итак, на основе анализа действующего федерального законодательства, устанавливающего основные полномочия органов внутренних дел Российской Федерации, которые могут быть отнесены к потерпевшим по ст. 317 УК РФ, являются граждане России, служащие в органах внутренних дел, для которых охрана правопорядка согласно закону, является основной или одной из основных задач, и осуществляющие деятельность по охране общественного порядка и обеспечению общественной безопасности, а именно:

- лица, осуществляющие оперативно-розыскную деятельность;

- сотрудники органов внутренних дел, осуществляющие охрану общественного порядка и обеспечение общественной безопасности.

$$
* * *
$$

1. "Конституция Российской Федерации" (принята всенародным голосованием 12.12.1993) (с учетом поправок, внесенных Законами РФ о поправках к Конституции РФ)

2. "Уголовный кодекс Российской Федерации" от 13.06.1996 N 63-Ф3 (с изм. и доп.)

3. Федеральный закон от 07.02.2011 N 3-Ф3 "О полиции"

4. Указ Президента РФ от 01.03.2011 N 250 "Вопросы организации полиции"

$\begin{array}{llllrlr}\text { 5. Приказ } & \text { МВД } & \text { России } & \text { от } & 17.01 .2006 & \mathrm{~N} & 19\end{array}$ "О деятельности органов внутренних дел по предупреждению преступлений" (вместе с "Инструкцией о деятельности органов внутренних дел по предупреждению преступлений")

6. Приказ МВД России от 29.01.2008 N 80 "Вопросы организации деятельности строевых подразделений патрульно-постовой службы полиции" (вместе с "Уставом патрульно-постовой службы полиции") (Зарегистрировано в Минюсте России 05.03.2008 N 11290)

7. Акимова Н.В. Виктимологические аспекты преступлений, совершаемых в отношении сотрудников органов внутренних дел "Российский следователь", 2006, N 1.

8. Курилов С.И.Исторический аспект развития научной мысли о нормах и институтах Общей части Уголовного кодекса Российской Федерации, непосредственно направленных на предупреждение преступлений // Сборник статей по материалам V Международной научно-практической конференции «Научные тенденции: Юрисприденция» 20.05.20017г. Изд. ЦНК МНИФ «Общественная наука». М. 2017 г. С.14-16. 
9. Лупов Д.В., Титушкина Е.Ю. Уголовно-правовая охрана жизни и здоровья лиц, выполняющих общественные обязанности в сфере охраны общественного порядка // Российский следователь. 2009. № 15 .

10. Криминология: Учебное пособие / Под ред. Н.Ф. Кузнецовой, В.В. Лунеева. 2-е изд., перераб. и доп. M., 2011.

11. Криминология: Учебник / Под ред. В.Н. Кудрявцева и В.Е. Эминова. 3-е изд., перераб. и доп. М., 2011.

12. Криминология: Учебник для вузов под ред. В.Д. Малкова "Юстицинформ", 2011. 